\title{
Court Trials
}

\author{
... in Egypt \\ By MONIKA LiNDBEKK and TERESA PEPE
}

The court sessions that attract public attention this year in Egypt are of a very different type than those held in Tunisia [ $\nearrow$ Public Hearings]. Above a court house located next to the criminal court at a busy intersection in Cairo, the following words are inscribed on thick concrete walls above noisy traffic: "God" (Allāh), "Right" (haqq), "Justice" ('adl). Lady Justice sits perched on the wall of a house adjacent to another urban court house. We are in the neighbourhood of Būlāq, a busy downtown district that, besides the court houses, hosts a second-hand market, metalworking and machines shops, and a number of street cafes. The entrance to the Criminal Court lies on a side street. There is hardly any control at the door, despite the huge amount of people constantly coming in and out. Once inside, one realizes that the building does not offer any relief from the chaos and dust of the street outside. Hundreds of regular citizens and street vendors roam from one corridor to another, across the floors. There are several trials going on simultaneously in the courtrooms. Most of them include a bench for the judge, lines of old stalls, occupied by the public attending the trial, and a cage in which the defendant is locked while waiting for the verdict. The voices of the jury cross with those of crying women and tea-vendors, to the point that it is almost impossible to hear what is going on.

Egyptians frequently resort to the courts to claim their rights in personal matters, ranging from establishing marriage and paternity to bringing charges of defamation (MadàMașr [d]). Thus, there is considerable interaction between these state institutions and the people. Since 2011 , courts have also been an important locus for the negotiation of the relationship between rulers and citizens, especially in the area of criminal law [ $\lambda^{6}$ The System" vs. "The People"]. Egyptians were hypnotized in the beginning of the trial against Husnī Mubārakknown as the "trial of the century"-in which he was charged with killing protestors. But the lengthy court proceedings have led to a sense of apathy. On January 9, the Court of Cassation upholds a conviction of former president Mubarak and his two sons on corruption charges (the only successful prosecution brought against him). Mubarak has already completed his three-year-prison sentence by opting to stay in the Maadi Military Hospital to receive medical treatment (ESSAM EL-DIN). He is therefore technically a free man; yet he remains confined at Maadi Military Hospital. At the hospital he is able to receive visits from guests and use personal phones. His wife Suzanne is also allowed to stay with him. On May 5, supporters of the former president gather in front of the hospital. While engaging in traditional dance accompanied by music, they wave pink balloons and pictures of Mubarak to celebrate his $88^{\text {th }}$ birthday. An elderly man laments, "Everyone now fears for the future and is terrified of the present. During his days we had simple lives, yet it was life" [ $\nearrow$ Present = Past (Stuck)] Looking pale and wearing a presidential suit, Mubarak appears in a hospital window and waves back. Meanwhile, another deposed president Muhammad Mursī is detained at a highsecurity prison near Alexandria. On November 15, the Court of Cassation revokes Mursī's 
death sentence and orders a retrial on the charge of conspiring to commit terrorist acts with foreign groups. One of Mursī's lawyers says: "He already has a final sentence of 20 years in prison. But at least today he gets to take off the red suit." Prisoners awaiting the death penalty in Egypt wear red jumpsuits while others wear blue (HADID).

Mubarak's limbo status at a Cairo hospital and Mursi's incarceration at a high-security 7 Prison are reflective of how post-2011 criminal justice has been shaped by changes in the political landscape. An important part of court trials is the production of legal facts which form the basis for evaluation of the disputing parties' claims as legal or illegal. Yet court trials, which frequently dominate the newspapers, have the appearance of being carefully orchestrated spectacles designed to inspire fear and awe of the state $[\lambda$ Security $=$ Fear (Police State)] and make important points to the public about the limits of freedom and rights rather than observing sound legal methods. Some also entertain doubts about the impartiality and independence of the judiciary and believe that the judicial system is being controlled by the executive and - by extension - the military: Street art shows a sexualized Lady Justice, depicted as a belly dancer wearing a military beret. Such apathy and scepticism are amplified by statements by judges that testify to a lack of tolerance for dissent and criticism of the government, and limitations on the freedom of opinion and expression. In a statement signaling justice with a vengeance, Minister of Justice Ahmad al-Zind said in January that he would not be satisfied until " 10,000 Brotherhood members were killed for every martyr" from the armed forces and the police [ $\lambda$ "The System" vs. "The People"; $\lambda$ True vs. False]:

I swear by God Almighty that, personally, the fire in my heart will not be extinguished unless for each one there's at least 10,000. (MadàMașr [e])

However, not only members of the Muslim Brotherhood are perceived as a challenge to Egyptian statehood and Egyptianness, but also other sectors of the opposition, intellectuals, and artists. In a series of trials, four Coptic Orthodox teenagers (MadàMașr [b]), the poet Fatima Naoot (Fāțima Nā'ūt) and the novelist Ahmed Naji (Aḥmad Nāgī) receive jail sentences in January and February for blasphemy or offending public morals. Fatima Naoot receives a three-year prison sentence and 20,000 EP fine for having published, back in 2014, a Tweet criticizing the ritual sacrifice of animals during 'Īd al-Aḍà̀. She has to defend herself against the accusation of insulting Abrahamic religion and propagating atheism in words, according to the article 98 of the Constitution (MadàMașr [a]). Ahmed Naji is given a twoyear sentence for publishing an excerpt from his recent novel Istikhdām al-Hayāt (Using Life, 2014) in the literary magazine Akhbār al-Adab, an excerpt that is deemed to have offended public morals. The accusation came, in August 2014, from an Egyptian citizen named Hany Saleh Tawfik (Hānī Șālih Tawfìq) who declared that he used to buy the journal regularly for his daughters, but that one time, his wife walked into the room showing him Naji's chapter and ridiculing him for bringing such writing into their home. Tawfì declared that upon reading the novels' excerpts, "his heartbeat fluctuated, his blood pressure dropped and he became severely ill" (KAREEM). Consequently, he went to court and filed a case against the author of the text, Ahmed Naji, and the magazine's editor-in-chief, Tarek al-Taher (Țāriq alȚāhir), for having published a "sexual article" that harmed not only his health and morals, but also the morals of Egypt as a whole [ $\nearrow$ The Honourable Citizen]. The public prosecutor

jais • 21 (2021) - Themed Section In2016: *64-*70 
decided to accept Hany Saleh's accusation and press charges against Naji, and so the trial started in December 2015.

The chapter under accusation is narrated from a first person perspective by the main character, Bassām Bahgat. It contains explicit description of a sexual intercourse and hashish smoking - as many works of Arabic literature do-and explicit sexual expressions such as "pussy," "cock," "licking," "sucking." Hany Saleh's accusation assumes that the text published is an article, and not part of a novel, and therefore attributes the harmful thoughts and actions of the novel's protagonist to the author himself. During the first trial, held in December 2015, the well-known novelist Sonallah Ibrahim (Șun` Allāh Ibrāhīm) and the Head of the General Egyptian Book Organization, Seif Salmawy (Sayf Salmāwī), had testified that the text in question is a novel, a piece of fiction, not one of journalism. In early January 2016, Naji and his editor are acquitted, according to Article 67 of the Egyptian Constitution, drafted in 2014, which forbids the jailing of artists and writers for publishing their work and explicitly guarantees freedom of artistic and literary creation, freedom of thought and opinion, and freedom of the press. However, the prosecution appeals the case, and on February 20 Naji is condemned to two years imprisonment, according to Article 178 of the Penal Code, which criminalizes content that violates public morals. The court argues that Article 67 of the Constitution, which guarantees the freedom of artistic and literary creativity, is not intended to protect those who claim to be writers, while in reality they succumb to "corrupt morals with their poisoned pens under the guise of freedom of thought" (Egypt Art on Trial). According to the court, the author is driven by the criminal intention "to submerge the youth in an atmosphere of moral depravity in order to inflict moral vices on them and awaken their lust." Tarek el-Taher, Akhbār al-Adab's editor-in-chief, is also accused of neglecting his responsibilities as editor-in-chief of the magazine, "since he did not prohibit the publication which could damage public order or violate public modesty," and forced to pay a fine of 20,000 EP. Egypt's literary and political communities respond by expressing widespread support for Naji. Seven members of the committee that wrote the Egyptian Constitution publish a statement in February condemning Naji's sentencing as unconstitutional, arguing that the conviction contravenes Article 67 of the Constitution (Ahram Online [b]). In February, over 600 Egyptian writers and artists in solidarity with Naji sign a statement criticizing the government's "multi-armed attack on a number of writers and journalists because of their opinions" and the "terrible and terrifying path taken by the regime that leads the entire country towards the abyss, through "assassinating" the public space of expression and confiscating the political space" (Egypt Solidarity). Naji's lawyers submit a motion to the Prosecutor General arguing that the sentence against Naji should not be implemented since it violates the Egyptian Constitution. On December 18, the appeal is finally accepted. Naji's sentence is suspended, but his freedom is nonetheless restricted by a travel ban which forbids the author from travelling outside Egypt.

By posing as the protector of public order, morality and religious emotions, the courts thus authorize intervention in the domain of belief [ $\nearrow$ Freedom vs. Constraint (Individual vs. Collective); $\lambda$ In Islam,... . Aside from the spectacle of state power, some court trials have added drama because individual actors do not carry out the roles as expected and produce alternative stories about what happened. During a hearing in the Criminal Court of South Cairo on April 27, activist Sana Seif (Sanā' Sayf) refuses to cooperate with the investing judge and

jaig • 21 (2021) - Themed Section In2016: *64-*70 
answer his questions, arguing that the investigation was merely a formality (șurr $\bar{l}$ ) ('ABD AL'ULÀ \& MABRŪK). She has been caught up in a government crackdown on dissenters after calling for protests against president al-Sisi for transferring two uninhabited Red Sea islands, Tīrān and Șanāfir, to Saudi Arabia. Sana Seif elaborates by saying:

Given that the judicial system has lost its sovereignty, in terms of issuing its own decisions, as it has lost its impartiality, as well as its commitment to the enforcement of justice; and given that executive authorities are the ones running this state - I see that this investigation is merely a guise, and this is why I refuse to deal with it (MadàMașr [c]). [ 7 Voice vs. Silence]

With this she expresses her belief that the trial was a mere charade and that the judiciary has betrayed the legacy of independence that judges during the pre-2011 era fought long and hard to achieve [ $\lambda$ Present $=$ Past (Stuck)]. She is punished for this with a six-month jail sentence on the charge of defaming the judiciary after being freed by a presidential pardon in another case. On February 13, 115 defendants are sentenced all at once in the West Cairo Military Court for participating in a demonstration which took place in 2014. Sixteen of the defendants are tried in their presence while 100 are sentenced in absentia for protesting against the ouster of president Muhammad Mursī. Among those convicted is 4-year-old Ahmed Mansour (Aḥmad Manșūr) who has not bothered to appear because he is playing at home. He is subsequently convicted of four counts of murder, eight counts of attempted murder and vandalizing government property. Pervading the story of Ahmed Mansur is an emotion of despair which conveys a profound sense of the opacity and unaccountability of the state toward its citizens, particularly those without legal representation [ $\lambda$ "The System" $v$ s. $^{\text {"The }}$ People", $\lambda$ Hope vs. Hell]. Yet, it also shows that court trials can function as vehicles for the voicing of alternative versions of events, this time outside the courtroom [ $\lambda$ Voice vs. Silence]. The spectacle continues outside court as the child's father appears on the ' 10 o'clock' show of the private channel DreamTV with Ahmed who is fast asleep on his father's lap (Ahram Online [a]). During the show, Ahmed Mansour's father explains that it all started in January 2014, when the $\nearrow$ The Policeman Criminal came asking for his son Ahmed at their house. Mansour showed them his child — who was two years old at the time - so they took him instead. The father says he was detained for four months, as the police thought he was Ahmed, his son. He added that he could not afford a lawyer until he appeared in front of the judge, who read his son's birth certificate, realized the mistake in the papers, and released the father without bail. However, two years on and Ahmed Mansour is still sentenced to prison. "I swear I don't want to upset anyone," pleads the father. "Please don't take my son!" (BBC World, BBC Masr). In an article featured in al-Ahrām on February 21, a spokesman of the Ministry of the Interior says there was a mistake in the name of the defendant, and the child's uncle, a man in his fifties, is the one who is wanted by the police (Ahram Online [a]). However, Ahmed Mansour's lawyer says they repeatedly called for correcting the mistake or to remove the name of the child from the case but they received no response. According to the defense lawyer, the fact that the court got past the sentencing state of hearing before realizing their mistake "proves that the judge did not read the case" (BBC Masr). He attributes the mix-up to a larger pattern of unaccountability of security forces in the country. The host of the 10 o'clock program describes the case against Ahmed Mansur as a "mark of shame"

jais • 21 (2021) - Themed Section In2016: *64-*70 
since it is characterized by flagrant and repeated violations of the rights of defense and the right to a fair trial. The programme host points out that such cases tarnish Egypt's image abroad where such miscarriages of justice are viewed as a hallmark of authoritarian regimes. He sounds a warning note by adding that the national project of the president is fast losing support due to such severe and unacceptable mistakes (AYMAN) [ $\nearrow$ True vs. False]. The case is also used by local human rights organizations to draw attention to hasty, legal proceedings in military courts and call for their end. According to Human Rights Watch, most civilians tried in military courts are sentenced after mass trials-like Ahmed Mansur-that violate fundamental due process rights, and some courts rely on confessions extracted under torture (Human Rights Watch, April 13).

Other sources of added drama stem from within the judiciary itself. The Egyptian judiciary has a strong professional identity as protectors of the State and public order. As alluded to by Sana Seif, this has historically been used by Egyptian courts to alternate between deference to the executive and accommodating public opinion. The rhetoric of state sovereignty invoked against dissenters can therefore be wielded both in favour of and against the interests of the executive. On June 21, the first circuit of the Egyptian State Council's administrative court sides with human rights lawyers contesting the executive's transfer of Tīrān and Șanāfîr, the two $\nearrow$ Red Sea Islands, to Saudi Arabia, instead asserting complete Egyptian sovereignty over the islands. The Court's conception of truth resonates with popular perceptions that ownership of the land was earned by the blood shed by Egyptians during the 1967 war (El-GOHARI). In its search for accurate and objective information, the Court also has recourse to several maps submitted by human rights lawyers for the purpose of finding hidden messages pertaining to the constitution of political and military power in this area. Since Egyptian maps stored by the national archive can only be issued to citizens pursuant to a security clearance (al-Mawqif al-Mișri) , it is not incidental that the maps submitted by human rights lawyers to the court include maps issued by a range of non-Egyptian authorities, including copies of pages from the Finnish orientalist George August Wallin's book Notes Taken During a Journey Through Part of Northern Arabia in 1848, Academic Atlas published by Cambridge University in 1940, and a 2000 issue of the Historical Atlas of the Kingdom of Saudi Arabia, created and issued by the King Abdulaziz Foundation For Research and Archives. On the other hand, the government contends that Egypt began leasing Șanāfir and Tīrān in 1950 to keep them from being seized by Israel at a time when Saudi Arabia was too weak to defend them. To support the claim, al-Sisi's administration points to a 1990 decree by former Egyptian President Hosni Mubarak that demarcated the maritime border between Egypt and Saudi Arabia, placing the islands' control beyond Egyptian territorial waters. According to the government, the court's account of what happened is not a truthful and accurate description of the facts. Hours after the ruling is announced, the State Lawsuits Authority, appeals the verdict and the cabinet says it will submit documents, among them maps and treaties that confirm Saudi sovereignty of the islands [ $\nearrow$ True vs. False]. This shows that the trials continue to be used as a site or battle over the 'truth' about what happened in a specific case as well as express dissent against executive authority, inside and outside the courtroom. 


\section{Related Entries}

ARrays - The Honourable Citizen $\downarrow$ In Islam, ... $\downarrow$ The Policeman Criminal $\downarrow$ Prison $\diamond$ Public Hearings $\checkmark$ Red Sea Islands

CODEs - Hope vs. Hell $\downarrow$ Freedom vs. Constraint (Individual vs. Collective) " "The System" vs. "The People" True vs. False Voice vs. Silence

CODES COLLAPSED - Present $=$ Past $($ Stuck $) \diamond$ Security $=$ Fear $($ Police State $)$

\section{References}

'ABD AL-'UlÀ, 'Umar, and Fāṭima MABRŪK. "'Ūlà jalasāt muḥ̄̄kamat Sanā’ Sayf li-'ihānat al-qaḍāa." Akhbār al-Yawm, May 4, 2016, >https://akhbarelyom.com/news/newdetails/5768/1/ولى-جلسات محاكمة_سناء-سيف_لإهانة_القضاء-الأربعاء

A7A News Agency / Wikālat P.ḥ.ā lil-'Anbā'. "Qișșa qașira.” A7A / P.ḥ.ā, March 3, 2016, <https:// mobile.twitter.com/hashtag/عواد_باع_أرضك?src=hash\&amp\%3Bref_src=twsrc\%5Etfw>.

[Ahram Online (a) =] N. N. "Father of 4-year-old sentenced to life in prison speaks out." al-Ahram Online, February 21, 2016, <http://english.ahram.org.eg/NewsContentP/1/188162/Egypt/Fatherof-year-old-sentenced-to-life-in-prison-spe.aspx $>$.

[Ahram Online (b) =] N. N. “'Writer Ahmed Naji's jail verdict unconstitutional,' say 7 authors of Egypt's constitution." Ahram Online, February 24, 2016, <http://english.ahram.org.eg/News Content/1/64/ 188406/Egypt/Politics-/Writer-Ahmed-Najis-jail-verdict-unconstitutional,-.aspx>.

Ayman, Sharīf. "Ba'd al-hukm al-mu’abbad 'alà țifl dhī 4 sanawāt.. al-Ibrāshī: wașmat 'ār fĩ haqaq alniz̄ām." Masrawy, February 21, 2016, <http://www.masrawy.com/News/News_Egypt/details/

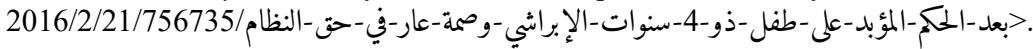

[BBC Masr =] N. N. "al-Hukm bi'l-mu'abbad 'alà tịfl "umruh 4 sanawāt'." BBC Arabic, February 19, 2016, <http://www.bbc.com/arabic/worldnews/2016/02/160219_egypt_child_sentence>.

$[$ BBC World =] N. N. "Egyptian four-year-old's life sentence a mistake, military says." BBC News, February 21, 2016, <http://www.bbc.com/news/world-middle-east-35633314>.

[Egypt Art on Trial =] N. N. "Court's Reasoning for \#AhmedNaji's Prison Sentence". Egypt Art on Trial - Didd muhākamat al-khayāl, Facebook Page, March 8, 2016, <https://www.facebook.com/ notes/egypt-art-on-trial-ضلخد-محاكة-الخيال/courts-reasoning-for-ahmednajis-prison-sentence/ $1736188856616584>$.

[Egypt Solidarity =] N. N. "Open up the public space: Solidarity with Egyptian writers' protest." Egypt Solidarity: an international initiative against repression in Egypt, [no date], $<$ https://egyptsolidarityinitiative.org/open-up-the-public-space-solidarity-with-egyptian-writersprotest/>.

EsSAM El-Din, Gamal. "Mubarak appeal rejected.” Al-Ahram Weekly, no. 1278, January 14-20, 2016, $<$ http://weekly.ahram.org.eg/News/15231.aspx>.

El-GoHARI, Muhammad. "What Was in the Egyptian Court's Reasoning in the Tiran and Sanafir Case?" Atlantic Council, June 24, 2016, <http://www.atlanticcouncil.org/blogs/menasource/what-was-inthe-egyptian-court-s-reasoning-in-the-tiran-and-sanafir-case>.

HADID, Diaa. "“Court in Egypt Overturns Mohamed Morsi's Death Sentence." New York Times, November 15, 2016, <https://www.nytimes.com/2016/11/16/world/middleeast/egypt-court-morsideath-sentence.html>.

Human Rights Watch. "Egypt: 7,400 Civilians Tried In Military Courts: Torture, Disappearances Used to Elicit Confessions." Human Rights Watch, April 13, 2016, <https://www.hrw.org/news/ 2016/04/13/egypt-7400-civilians-tried-military-courts>.

jais • 21 (2021) - Themed Section In2016: *64_*70 
KAREem, Mona. "The Persecuted Novelist of Dystopian Cairo: Mona Kareem interviews Ahmed Naji." LA Review of Books, January 11, 2016, <https://lareviewofbooks.org/article/the-persecutednovelist-of-dystopian-cairo>.

[MadàMașr (a) =] N. N. "Poet Fatima Naoot sentenced to 3 years in prison for contempt of religion." MadàMaṣr, January 26, 2016, <https://www.madamasr.com/en/2016/01/26/news/culture/poetfatima-naoot-sentenced-to-3-years-in-prison-for-contempt-of-religion/>.

[MadàMașr (b) =] N. N. "al-Hukm 'alà thalāthat 'ațāl 'aqbāt bi-sijn 5 sanawāt bi-tuhmat 'ihānat al'islām.' MadàMaṣr, February 25, 2016, <https://www.madamasr.com/ar/2016/02/25/feature/

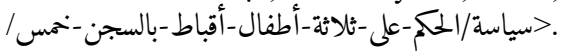

[MadàMașr (c) =] N. N. "Activist Sanaa Seif released, accused of insulting official during investigation.” MadàMașr, April 27, 2016, <https://www.madamasr.com/en/2016/04/27/news/u/ activist-sanaa-seif-released-accused-of-insulting-official-during-investigation/> .

[MadàMașr $(\mathrm{d})=$ ] N. N. "Actor Ahmed Ezz sentenced to 3 years in prison for defaming actress Zeina in paternity case." MadàMașr, July 27, 2016, <https://www.madamasr.com/en/2016/06/19/news/u/ actor-ahmed-ezz-sentenced-to-3-years-in-prison-for-defaming-actress-zeina-in-paternity-case/amp/>

[MadàMașr (e) =] N. N. "HRW lambasts justice minister's incitement to k.ill 10,000 MB for every dead soldier." MadàMașr, February 9 2016, <https://www.madamasr.com/en/2016/02/09/news/ u/hrw-lambasts-justice-ministers-incitement-to-kill-10000-mb-for-every-dead-soldier/>.

[al-Mawqif al-Mișrī =] N. N. "Ru’yā mișriyya min farīq șafḥat al-Mawqif al-Mișrī li-'azmat jazīratay Tīrān wa-Șanāfîr." Facebook page, April 11, 2016, <https://www.facebook.com/almawkef almasry/posts/774705619296004>.

4 monika.lindbekk@ub.no

$\checkmark$ teresa.pepe@ikos.uio.no

\section{... in Tunisia}

See $\nearrow$ Public Hearings 